\title{
Modeling and Optimization of a Residential Solar Stand-Alone Power System
}

\author{
Hany A. Khater, Amr A. Abdelraouf, and Mohamed H. Beshr \\ Department of Mechanical Power Engineering, Faculty of Engineering, Cairo University, P.O. Box 12211, Giza, Egypt \\ Correspondence should be addressed to Mohamed H. Beshr, mbeshr@ymail.com
}

Received 22 July 2011; Accepted 25 August 2011

Academic Editors: O. O. Fasina and Z. Oktay

Copyright (๑) 2011 Hany A. Khater et al. This is an open access article distributed under the Creative Commons Attribution License, which permits unrestricted use, distribution, and reproduction in any medium, provided the original work is properly cited.

\begin{abstract}
Modeling and optimization of a residential solar-powered stand-alone power system comprising photovoltaic (PV) arrays and secondary batteries are presented. Moreover, an economic study is performed to determine the cost of electricity (COE) produced from this system so as to determine its competitiveness with the conventional sources of electricity. All of the calculations are performed using a computer code developed by using MATLAB. The system output was calculated for Cairo city $\left(30^{\circ} 01^{\prime} \mathrm{N}\right.$, $31^{\circ} 14^{\prime} \mathrm{E}$ ) in Egypt. It was found that dual-axis solar tracking is not economically feasible while cooling of the PV surface helps to lower the COE of the system. Also, the average maximum efficiency of the modeled $200 \mathrm{~W}$ solar cells was $14.16 \%$. The system which has an efficiency of $12 \%$ showed a great ability to satisfy the estimated demand load. The COE obtained from the system was found to be 41.7 cents/kWh over 20 years of its operation with an expected future cost of 31 cents/kWh.
\end{abstract}

\section{Introduction}

The use of nonrenewable fuel diminishes as time goes on. This is simply because such type of fuel will vanish at some point of time. Thus, the need of renewable sources of energy becomes a fact of life. Using solar energy seems to be a promising source of energy. However, some serious concerns about its implementation include the cost of electricity obtained from a solar source as well as the intermittent nature in solar power production. In order to overcome the latter concern, a secondary battery is used in the modeled system for storage of the electricity. Also, this paper focuses on the economic analysis, system sizing, and optimization of the stand-alone solar power system.

This paper is divided into 5 parts, as shown in Figure 1. In the first 2 parts, the methods for calculation of solar radiation as well as the modeling of the performance of the PV arrays are described. Then, the basic model used to determine the cost of electricity (COE) obtained from the model is presented. Added to that, the method used to determine the demand load and hence the size of the system is explained. Finally, an optimization of the system is developed so as to determine the lowest possible cost of electricity, and the output of the optimized system throughout the year in Cairo is presented.

\section{Solar Radiation Estimation}

The following procedure utilizes the basic solar equations and empirical models to estimate the amount of solar radiation falling on the PV arrays tilted with an angle $\beta$ with the horizontal [1]:

$$
\begin{gathered}
\delta=23.45 * \sin \left[360 *\left(\frac{284+n}{365}\right)\right], \\
\omega=15\left(t_{s}-12\right),
\end{gathered}
$$

where $\delta$ is the declination angle in degrees; $n$ is the number of days ( $n=1$ for 1st of January); $\omega$ is the hour angle; $t_{s}$ is the solar time;

$$
\begin{gathered}
\sin \left(\alpha_{a}\right)=\sin (\delta) \sin (\phi)+\cos (\delta) \cos (\phi) \cos (\omega), \\
\omega_{s}=\cos ^{-1}(-\tan (\delta) \tan (\phi)), \\
S_{o}=\frac{2 \omega_{s}}{15}
\end{gathered}
$$




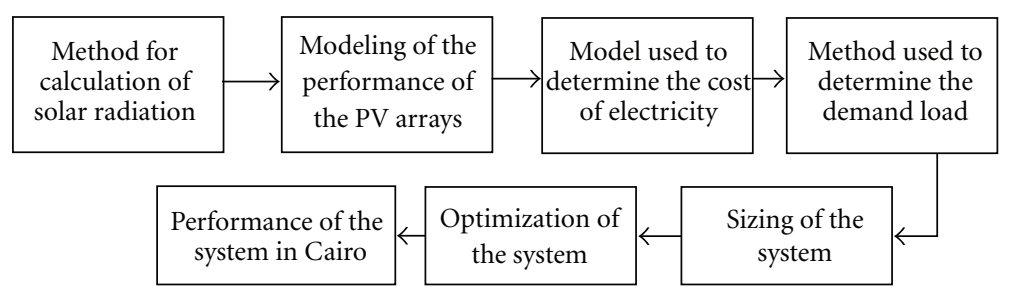

Figure 1: Paper outline.

where $\alpha_{a}$ is the altitude angle; $\varphi$ is the latitude $\left(30^{\circ}\right.$ for Cairo); $\omega_{s}$ is the sunrise or sunset angle in degrees; $S_{o}$ is the theoretical duration of sunlight;

$$
\begin{aligned}
G_{o}= & G_{\mathrm{sc}}\left[1+0.034 \cos \left(\frac{360 n}{365.25}\right)\right], \\
H_{o}= & 24 * 3600 * \frac{G_{\mathrm{sc}}}{\pi}\left[1+0.033 \cos \left(\frac{360 n}{365}\right)\right] \\
& *\left[\cos (\delta) \cos (\phi) \sin \left(\omega_{s}\right)+\pi \frac{\omega_{s}}{180} \sin (\delta) \sin (\phi)\right],
\end{aligned}
$$

where $G_{o}$ is the extraterrestrial solar radiation $\left(\mathrm{W} / \mathrm{m}^{2}\right) ; G_{\text {sc }}$ is the solar constant $=1367 \mathrm{~W} / \mathrm{m}^{2} ; H_{o}$ is the extraterrestrial irradiation available per day assuming that the sky is clear $\left(\mathrm{J} / \mathrm{m}^{2} \cdot\right.$ day $)$

$$
\begin{aligned}
K_{T} & =\frac{H}{H_{o}}, \\
\bar{K}_{T} & =\frac{\bar{H}}{\bar{H}_{o}},
\end{aligned}
$$

where $K_{T}$ is the clearness index; $\bar{K}_{T}$ is the monthly average daily clearness index; $H$ is the irradiation available per day $\left(\mathrm{J} / \mathrm{m}^{2} \cdot\right.$ day $)$. The value of the clearness index is obtained through the Ångström-type regression equation; the Ångström-type regression equation [2]:

$$
\frac{\bar{H}}{\bar{H}_{o}}=\bar{a}+\bar{b}\left(\frac{S}{S_{o}}\right),
$$

where $S$ is the actual duration of sunlight; $a$ and $b$ are empirical constants. However, Khalil and Fathy [3] provided values of $\bar{a}$ and $\bar{b}$ which will be used in our design as these values yield estimated values of solar irradiation with good agreement with the measured values or solar irradiation at Cairo. These values were

$$
\begin{gathered}
\bar{a}=0.461, \\
\bar{b}=0.259 .
\end{gathered}
$$

Also, the values of $S / S_{o}$ provided by Khalil and Fathy [3] are shown in Table 1.
The diffuse irradiation available per day $\left(H_{d}\right)$ is obtained from the Collares-Pereira correlation [4] (for $0.17<K_{T}<$ 0.75):

$$
\begin{gathered}
\frac{H_{d}}{H}=1.188-2.272 K_{T}+9.473 K_{T}^{2}-21.865 K_{T}^{3}+14.648 K_{T}^{4}, \\
r_{t}=\frac{G}{H}
\end{gathered}
$$

where $G$ is the solar radiation $\left(\mathrm{W} / \mathrm{m}^{2}\right)$. Collares-Pereira and Rabl [4] provides the following relation for $r_{t}$ :

$$
r_{t}=\frac{\pi}{24}(a+b \cos (\omega)) \frac{\cos (\omega)-\cos \left(\omega_{s}\right)}{\sin \left(\omega_{s}\right)-\left(\pi \omega_{s} / 180\right) \cos \left(\omega_{s}\right)},
$$

where

$$
\begin{aligned}
& a=0.409+0.5016 \sin \left(\omega_{s}-60\right), \\
& b=0.6609-0.4767 \sin \left(\omega_{s}-60\right) .
\end{aligned}
$$

Also, Liu and Jordan [5] provide the following relation for $r_{d}$, the ratio of hourly diffuse to daily diffuse radiation, as a function of day length and the hour in question:

$$
r_{d}=\frac{\pi}{24} \frac{\cos (\omega)-\cos \left(\omega_{s}\right)}{\sin \left(\omega_{s}\right)-\left(\pi \omega_{s} / 180\right) \cos \left(\omega_{s}\right)} .
$$

It was suggested by Liu and Jordan [6] that the radiation $\left(G_{g, t}\right)$ on a surface tilted with angle $\beta$ with the horizontal was considered to include three components: beam $\left(G_{g, t}\right)$, isotropic diffuse $\left(G_{d, t}\right)$, and solar radiation diffusely reflected from the ground $\left(G_{r}\right)$. The radiation on the tilted surface is expressed in $\mathrm{W} / \mathrm{m}^{2}$ as

$$
G_{g, t}=\underbrace{G_{b} R_{b}}_{G_{b, t}}+\underbrace{G_{d}\left(\frac{1+\cos (\beta)}{2}\right)}_{G_{d, t}}+\underbrace{G \rho_{g}\left(\frac{1-\cos (\beta)}{2}\right)}_{G_{r}},
$$

where

$$
\begin{gathered}
G_{b}=G-G_{d}, \\
R_{b}=\frac{\cos (\phi-\beta) \cos (\delta) \cos (\omega)+\sin (\phi-\beta) \sin (\delta)}{\cos (\phi) \cos (\delta) \cos (\omega)+\sin (\phi) \sin (\delta)},
\end{gathered}
$$

$\rho_{g}$ is the diffuse reflectance of the surroundings $=0.3$. 
TABLE 1: Monthly values of $S / S_{o}$.

\begin{tabular}{|c|c|c|c|c|c|c|c|c|c|c|c|c|}
\hline Month & Jan. & Feb. & Mar. & Apr. & May & Jun. & Jul. & Aug. & Sep. & Oct. & Nov. & Dec. \\
\hline$S / S_{o}$ & 0.598 & 0.647 & 0.689 & 0.771 & 0.815 & 0.859 & 0.883 & 0.809 & 0.731 & 0.702 & 0.693 & 0.645 \\
\hline
\end{tabular}

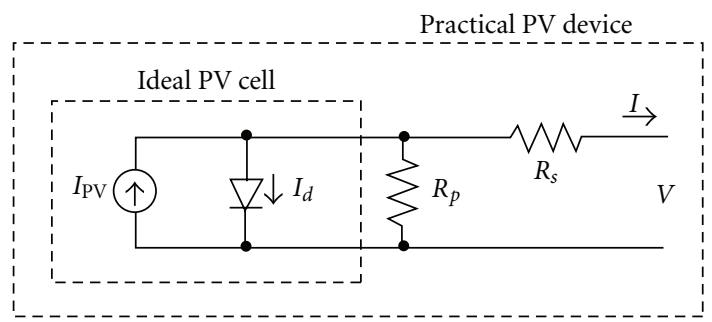

Figure 2: Single-diode model.

\section{Photovoltaic Modeling}

There are several models available for modeling of a practical photovoltaic cell. The general model, shown in Figure 2, consists of a current source, a parallel diode, a parallel resistor expressing leakage current, and series resistor describing an internal resistance to the current flow. In an ideal photovoltaic cell, there is no series loss and there is no leakage to the ground. That is, the series resistor has a value of zero while the parallel resistor has a value of infinity.

The current obtained from a photovoltaic module consisting of a number of cells $\left(N_{s}\right)$ connected in series is represented by [7]

$$
I=I_{\mathrm{pv}}-\underbrace{I_{0}\left[\exp \left(\frac{q\left(V+I R_{s}\right)}{a k T N_{s}}\right)-1\right]}_{I_{d}}-\frac{V+R_{s} I}{R_{p}},
$$

where $I_{\mathrm{pv}}$ is the current generated by the incident light (directly proportional to the Sun irradiation); $I_{d}$ is the Shockley diode equation; $I_{0}$ is the reverse saturation or leakage current of the diode; $q=1.60217646 \times 10^{-19} \mathrm{C}$ (the electron charge) $k=1.3806503 \times 10^{-23} \mathrm{~J} / \mathrm{K}$ (the Boltzmann constant); $T$ is the temperature of the $\mathrm{p}-\mathrm{n}$ junction (in Kelvin); $a$ is the diode ideality constant; $R_{s}$ is the series resistance; $R_{p}$ is the shunt resistance.

In the case of a number of modules connected in parallel $\left(N_{p}\right)$, the current obtained from (13) is multiplied by $N_{p}$. All PV array datasheets typically consist of the following: the nominal open-circuit voltage $\left(V_{\mathrm{oc}, n}\right)$, the nominal shortcircuit current $\left(I_{\mathrm{sc}, n}\right)$, the voltage at the maximum power point $\left(V_{\mathrm{mp}}\right)$, the current at the maximum power point $\left(I_{\mathrm{mp}}\right)$, the open-circuit voltage temperature coefficient $\left(K_{V}\right)$, the short circuit current temperature coefficient $\left(K_{I}\right)$, and the maximum experimental peak output power $\left(P_{\max , e}\right)$. This information is always provided with reference to the nominal condition or standard test conditions (STCs) of temperature $\left(25^{\circ} \mathrm{C}\right)$ and solar irradiation $\left(1000 \mathrm{~W} / \mathrm{m}^{2}\right)$. Some manufacturers provide $I-V$ curves for several irradiation and temperature conditions. The photovoltaic module used for the calculations in this paper is the multicrystalline silicon KC200GT manufactured by Kyocera [8]. The datasheet for this module contains all of the previously mentioned data. Also, the provided $I-V$ curves in the datasheet were used to validate the results of the PV model used in this study. For simplicity, the single diode model will be studied in this work. This model offers a good compromise between simplicity and accuracy [9];

$$
\begin{gathered}
I_{\mathrm{PV}}=\left(I_{\mathrm{PV}, n}+K_{I}\left(T-T_{n}\right)\right) \frac{G_{g, t}}{G_{n}}, \\
I_{\mathrm{PV}, n}=\left[\frac{R_{p}+R_{s}}{R_{p}}\right] I_{\mathrm{sc}, n}, \\
I_{\mathrm{sc}}=\left(I_{\mathrm{sc}, n}+\mathrm{K}_{I}\left(T-T_{n}\right)\right) \frac{G}{G_{n}},
\end{gathered}
$$

where $G_{n}=1000 \mathrm{~W} / \mathrm{m}^{2}$ (nominal solar radiation); $T_{n}=$ $298.15 \mathrm{~K}$ (nominal temperature); $K_{I}=3.18 \times 10^{-3} \mathrm{~A} /{ }^{\circ} \mathrm{C}$ (obtained from the KC200GT module datasheet); $I_{\mathrm{sc}, n}=8.21$ A (obtained from the KC200GT module datasheet). King et al. [10] found that there is typically less than a 5\% change in the voltage coefficients over a tenfold change in irradiance from $100 \mathrm{~W} / \mathrm{m}^{2}$ to $1000 \mathrm{~W} / \mathrm{m}^{2}$. The temperature of the $\mathrm{PV}$ module can be obtained from the following equation [11]:

$$
T-T_{a}=(219+832 \bar{K}) \frac{\text { NOCT }-20}{800},
$$

where $T_{a}$ is the ambient temperature which can be obtained from the weather data available for Cairo [12]; NOCT = $47^{\circ} \mathrm{C}$ (nominal cell operating temperature, obtained from the KC200GT module datasheet); $\bar{K}$ is the monthly clearness index. The equation above is valid when the array's tilt is equal to the latitude minus the declination. If the angle differs from this value the right side of (15) has to be multiplied by a correction factor $C_{f}$ defined by

$$
C_{f}=1-1.17 * 10^{-4}\left(s_{M}-s\right)^{2},
$$

where $s_{M}$ is the optimum tilt angle and $s$ is the actual tilt angle, both expressed in degrees.

The diode saturation current $I_{0}$ and its dependence on the temperature may be expressed by the following equation [13]:

$$
I_{0}=I_{0, n}\left[\frac{T_{n}}{T}\right]^{3} \exp \left[\frac{q E_{g}}{a k}\left(\frac{1}{T_{n}}-\frac{1}{T}\right)\right]
$$

where $E_{g}$ is the bandgap energy of the semiconductor = $1.12 \mathrm{eV}$. The nominal saturation current $I_{0, n}$ is obtained by 
evaluating (13) at the nominal open-circuit condition, with $V=V_{\mathrm{oc}, n,}, I=0$, and $I_{\mathrm{pv}} \approx I_{\mathrm{sc}, n}$

$$
I_{0, n}=\frac{I_{\mathrm{sc}, n}}{\exp \left[V_{\mathrm{oc}, n} / a V_{t, n}\right]-1}
$$

where $V_{t, n}=k T_{n} / a$.

The value of $a$ is stated by Tsai et al. [14] for different types of PV depending on the PV technology. For the calculations in this paper, the value of $a$ will be taken equal to 1.3. The method used here to get $R_{s}$ and $R_{p}$ is very simple. The first iterative value of $R_{s}$ is 0 . Then the value of $R_{p}$ will be calculated from (19) using the values at the nominal conditions which is obtained from the module datasheet. The value of the maximum power is then obtained from the graph $\left(P_{\max , m}\right.$, using a computer code) and compared with the experimental maximum power $\left(P_{\max , e}\right)$. This process is then repeated while increasing the value of $R_{s}$ by a small increment (e.g., 0.01) until the value of the calculated maximum power and the experimental one are equal (or close to each other within a certain tolerance, e.g., 0.001) [15]. It is worth noting that the values of both $R_{s}$ and $R_{p}$ obtained are for the nominal conditions. However, the changes in their values due to the temperature changes are small and can be neglected;

$$
R_{p}=\frac{V_{\mathrm{mp}}\left(V_{\mathrm{mp}}+\mathrm{I}_{\mathrm{mp}} R_{s}\right)}{\left[V_{\mathrm{mp}} I_{\mathrm{PV}}-V_{\mathrm{mp}} I_{0} \exp [\mathfrak{X}]+V_{\mathrm{mp}} I_{0}-P_{\mathrm{max}, e}\right]},
$$

where $\mathfrak{X}$ denotes $\left(\left(V_{\mathrm{mp}}+I_{\mathrm{mp}} R_{s}\right) / N_{s} a\right)(a / k T)$.

It is suggested to use maximum power point tracking (MPPT) which is a fully electronic system that varies the electrical operating point of the modules so that the modules are able to deliver maximum available power. Additional power harvested from the modules is then made available as increased battery charge current [16].

As shown in Figure 3, as the radiation level decreases, the maximum power that can be obtained from the module decreases. However, at every radiation level, the maximum power can be obtained at a certain voltage value which is different from one radiation level to another. At the same time, in case of not using MPPT, the operating voltage of the module is constant and equal to that of the load which is not equal to the optimum voltage. On the other hand, when using MPPT, the operating voltage varies according to the radiation level so that the module supplies the maximum power that it can provide at each radiation level. This of course causes an increase in the PV efficiency. This means that throughout the day the current will change. This change will cause a similar change in the battery charge current.

\section{Economic Analysis}

In order for the renewable energy to be more competitive to the conventional methods of power generation in the recent time, it needs to become more economic. That is, to have a lower cost on the long run. Thus, a very important part of the proposed model is to provide an economic study for the whole system. The main economic parameter that is studied

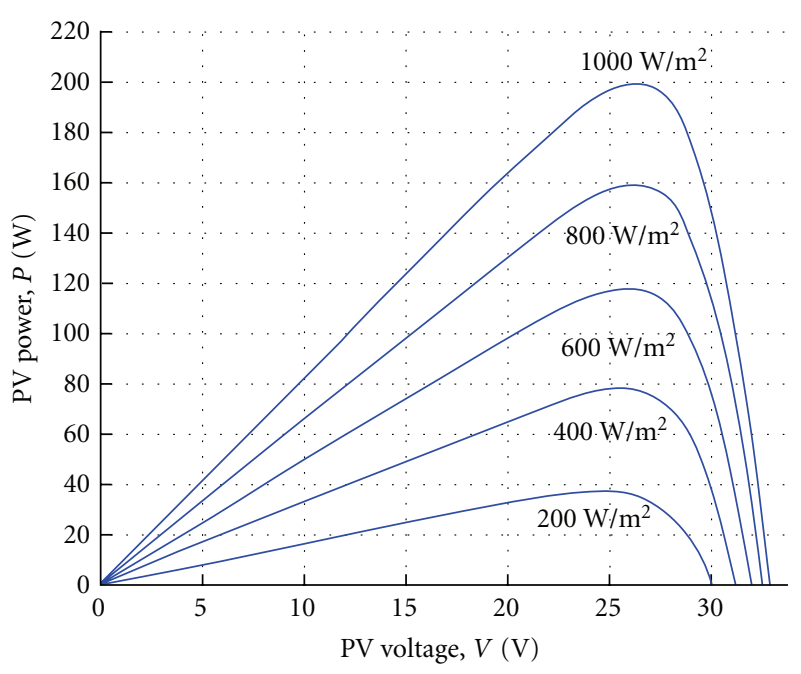

FIGURE 3: Variation of $P-V$ curves of KC200GT with radiation level.

is the cost of electricity (COE), which is the cost of producing one kWh of electricity. This parameter is believed to be the major criterion that indicates whether the system can be economically competitive to other conventional systems or not.

The main cost items that are included in this estimate are as follows.

(1) Photovoltaic panels.

(2) Battery.

(3) $\mathrm{DC} / \mathrm{AC}$ converter (inverter).

(4) Charge controller.

(5) Operating and maintenance cost $\left(C_{\mathrm{O} \& \mathrm{M}}\right)$.

(a) Capital Cost Estimation. The following assumptions are extracted from various literatures and are used to estimate the purchase cost of different system components excluding the taxes [17-19].

(1) Prevailing interest rate (ir) $=2 \%[17]$.

(2) Average inflation rate $(f)=2.72 \%$ (on US\$ basis) [18].

(3) Installation cost $=15 \%$ purchase cost [19].

(4) Operating and maintenance cost $=20 \%$ of annual fixed cost [19].

The specifications as well as the cost of each of the system's components are shown in Table 2 .

$$
\text { Capital cost }\left(C_{\text {cap }}\right)=\text { purchase cost }+ \text { installation cost. }
$$

It is worth noting that the equivalent capital cost of each replacement cost of the batteries needs to be included in the capital cost of the system according to the following relation:

$$
C_{\text {cap }, \text { replacement }}=\frac{C_{\text {PEMFC,replacement }}}{\left(1+\mathrm{ir}_{\text {eff }}\right)^{n}},
$$


TABle 2: System Components' estimated life and cost.

\begin{tabular}{lccc}
\hline Component & $\begin{array}{c}\text { Price } \\
\text { (US\$/Unit) }\end{array}$ & $\begin{array}{c}\text { Replacement time } \\
\text { (year) }\end{array}$ & Unit \\
\hline PV & 2640 & 20 & $1 \mathrm{~kW}$ \\
Inverter & 500 & 20 & $1 \mathrm{~kW}$ \\
Charge controller & 133 & 20 & $1 \mathrm{~kW}$ \\
Battery & 250 & 5 & $1 \mathrm{kWh}$ \\
\hline
\end{tabular}

where $n$ is the number of years, calculated from the moment of installing the system, after which the stack will be replaced.

The effective annual interest rate $\left(\mathrm{ir}_{\mathrm{eff}}\right)$ is:

$$
\mathrm{ir}_{\text {eff }}=\mathrm{ir}+f+\mathrm{ir} * f \text {. }
$$

(b) Estimation of Total Annual Cost (TAC) and Cost of Electricity (COE). The installation cost per kilowatt of system net electrical power can then be estimated as:

Installation cost per $\mathrm{kW}_{e}$

$$
=\frac{C_{\text {cap }}}{W_{\text {net,elec }}}\left(\frac{\$}{\mathrm{~kW}}\right) \text {, }
$$

Annual fixed charge rate (AFCR)

$$
=\frac{\mathrm{ir}_{\mathrm{eff}} *\left(1+\mathrm{ir}_{\mathrm{eff}}\right)^{\text {life }}}{\left(1+\mathrm{ir}_{\mathrm{eff}}\right)^{\text {life }}-1}
$$

Annual fixed charge (AFC)

$$
=C_{\text {cap }} * \mathrm{AFCR} \text {, }
$$

Total annual cost (TAC)

$$
=\mathrm{AFC}+\mathrm{C}_{\mathrm{O} \& \mathrm{M}}\left(\frac{\$}{\mathrm{yr}}\right) \text {, }
$$

Cost of electricity (COE)

$$
\begin{aligned}
= & \frac{\text { TAC }(\$ / \text { year })}{\left.\mathrm{W}_{\text {net,elec }}(\mathrm{kW}) * 24(\mathrm{hr} / \text { day }) * 365.25 \text { (day/year }\right)} \\
& \times\left(\frac{\$}{\mathrm{~kW}}\right) .
\end{aligned}
$$

\section{Demand Load}

The proposed system is applied to a residential house of area $140 \mathrm{~m}^{2}$ with 4 persons living in it. The estimated trend of the demand load represents the daily power consumption of a typical family [20]. From the midnight to early morning (00:00-04:00) all families are sleeping and thus the power requirement is low. This simply means that power is only needed to keep the household electronics and appliances, such as refrigerators and safety lighting operating. In the morning (04:00-07:00) and at noon (11:00-12:00), more
TABle 3: Hourly distribution of the low demand load.

\begin{tabular}{lccccc}
\hline Month & \multicolumn{5}{c}{ Hour of the day } \\
\hline \multirow{4}{*}{ March } & $0-4$ & $4-5$ & $5-6$ & $11-12$ & $18-23$ \\
April & $7-10$ & $6-7$ & $17-18$ & & \\
November & $13-16$ & $10-11$ & & & \\
& $23-24$ & $12-13$ & & & \\
& & $16-17$ & & & \\
\hline Load $(W)$ & 432 & 742 & 923 & 2543 & 1725 \\
\hline
\end{tabular}

Total daily $=21.476 \mathrm{kWh}$, total monthly $=644.28 \mathrm{kWh}$.

After taking into account the combined efficiency of the inverter and the battery:

Total daily $=24.697 \mathrm{kWh}$, total monthly $=740.922 \mathrm{kWh}$.

power is required for cooking, leisure, and so forth. From the evening to midnight (16:00-23:00), the consumption of electric power is considerable due to family activities. The automatic load evaluation form, shown in Figure 4, provided by ABS Alaskan, Inc., [21] was used to help in the load estimation process.

Tables 3, 4, 5, and 6 present the estimated hourly demand load for different months of the year in Cairo using the trend proposed by Hwang et al. [20] which is described before, and the load evaluation form [21]. It is worth noting that the values of demand load provided in the last row of each table are the values that need to be delivered to the house. However, the power to be supplied by the system should be 1.15 times the estimated demand load to account for the combined efficiency of the inverter and the battery so as to provide a stable alternating current (AC) electric power instead of fluctuating direct current (DC). The distributions shown in Tables 3, 4, 5, and 6 as well as Figures 5, 6, 7, and 8 are hourly distributions with 0 referring to midnight (start of the day) and 24 referring to the midnight of the following day (end of the day).

Table 3 shows the estimated demand load in March, April, and November. This load is expected to be the lowest throughout the year as these months have a moderate temperature which requires almost no conditioning. In other words, the load estimation during these months involves the use of the basic appliances such as refrigerators, lighting, computers, and television and does not involve air conditioning or air heaters.

Figure 5 demonstrates the actual required low demand load throughout the day in March, April, and November.

Table 4 shows the estimated demand load in May, and October. This load is considered as a medium load as these months have a slightly high temperature which requires the use of fans throughout the day causing an increase in the demand load. In other words, the load estimation during these months involves the use of the basic appliances such as refrigerators, lighting, computers, and television as well as fans.

Figure 6 demonstrates the actual required medium demand load throughout the day in May and October.

Table 5 shows the estimated demand load in January, February, and December. This load is considered as a medium or slightly high load as these months have a low 


\begin{tabular}{|c|c|c|c|c|c|c|c|c|}
\hline \multicolumn{3}{|l|}{ Load evaluation form } & \multicolumn{3}{|c|}{ Name: } & \multicolumn{3}{|l|}{ Date: } \\
\hline Appliance & $\mathrm{AC}$ & $\mathrm{DC}$ & Qty. & $\begin{array}{c}\text { Watts }(\mathrm{V} \times \mathrm{A}) \\
\mathrm{W} \times 1.15 \text { for } \mathrm{AC}\end{array}$ & Hrs/day & $\begin{array}{l}\text { Avg. Watts } \\
\text { Hrs/day }\end{array}$ & \multicolumn{2}{|c|}{ Calculators } \\
\hline$\square$ & 0 & $\mathrm{O}$ & 0 & $\mathrm{X} 0$ & $X 0.0$ & $=0.00$ & \multirow{4}{*}{\multicolumn{2}{|c|}{$\begin{array}{l}\text { Find the wattage of an } \\
\text { appliance from the } \\
\text { listed amps and volts }\end{array}$}} \\
\hline$\square$ & 0 & 0 & 0 & $\mathrm{X} 0$ & $\mathrm{X} 0.0$ & $=0.00$ & & \\
\hline$\square$ & 0 & 0 & 0 & $\mathrm{x} 0$ & $\mathrm{X} 0.0$ & $=0.00$ & & \\
\hline$\square$ & 0 & 0 & 0 & $\mathrm{X} 0$ & $\mathrm{X} 0.0$ & $=0.00$ & & \\
\hline$\square$ & 0 & 0 & 0 & $\mathrm{X} 0$ & $\mathrm{X} 0.0$ & $=0.00$ & \multirow{2}{*}{\multicolumn{2}{|c|}{$\begin{array}{l}\text { Volts: } \square \times \\
\text { Amps: } \square=\end{array}$}} \\
\hline$\square$ & 0 & $\mathrm{O}$ & 0 & $\mathrm{X} 0$ & $\mathrm{X} 0.0$ & $=0.00$ & & \\
\hline$\square$ & 0 & $\mathrm{O}$ & 0 & $\mathrm{X} 0$ & $\mathrm{X} 0.0$ & $=0.00$ & \multirow{3}{*}{0.00} & \multirow[b]{2}{*}{ (watts) } \\
\hline$\square$ & $\mathrm{O}$ & 0 & 0 & $\mathrm{X} 0$ & $\mathrm{X} 0.0$ & $=0.00$ & & \\
\hline$\square$ & 0 & 0 & 0 & $\mathrm{X} 0$ & $\mathrm{X} 0.0$ & $=0.00$ & & \\
\hline$\square$ & 0 & 0 & 0 & $\mathrm{X} 0$ & $\mathrm{X} 0.0$ & $=0.00$ & \multirow{4}{*}{\multicolumn{2}{|c|}{$\begin{array}{l}\text { Adjust the wattage for } \\
\text { an AC appliance to } \\
\text { adjust for estimated } \\
\text { inverter loss }\end{array}$}} \\
\hline$\square$ & 0 & 0 & 0 & $\mathrm{X} 0$ & $X 0.0$ & $=0.00$ & & \\
\hline$\square$ & 0 & $\mathrm{O}$ & 0 & $\mathrm{X} 0$ & $\mathrm{X} 0.0$ & $=0.00$ & & \\
\hline & 0 & $\mathrm{O}$ & 0 & $\mathrm{X} 0$ & $\mathrm{X} 0.0$ & $=0.00$ & & \\
\hline & 0 & 0 & 0 & $\mathrm{X} 0$ & $\mathrm{X} 0.0$ & $=0.00$ & \multirow{3}{*}{\multicolumn{2}{|c|}{$\begin{array}{cl}\text { Watts: } & \square \\
1.15 & \times \\
& \end{array}$}} \\
\hline$\square$ & 0 & $\mathrm{O}$ & 0 & $\mathrm{X} 0$ & $\mathrm{X} 0.0$ & $=0.00$ & & \\
\hline$\square$ & 0 & 0 & 0 & $\mathrm{X} 0$ & $\mathrm{X} 0.0$ & $=0.00$ & & \\
\hline & 0 & 0 & 0 & $\mathrm{X} 0$ & $\mathrm{X} 0.0$ & $=0.00$ & \multirow{2}{*}{0.00} & \multirow{2}{*}{ (AC Watts) } \\
\hline & 0 & 0 & 0 & $\mathrm{X} 0$ & $\mathrm{X} 0.0$ & $=0.00$ & & \\
\hline$\square$ & 0 & 0 & 0 & $\mathrm{X} 0$ & $\mathrm{X} 0.0$ & $=0.00$ & \multirow{2}{*}{\multicolumn{2}{|c|}{ Erase form }} \\
\hline [ & 0 & 0 & 0 & $\mathrm{X} 0$ & $\mathrm{X} 0.0$ & $=0.00$ & & \\
\hline 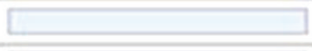 & 0 & $\mathrm{O}$ & 0 & $\mathrm{X} 0$ & $\mathrm{X} 0.0$ & $=0.00$ & & \\
\hline+2 & 0 & $\mathrm{O}$ & 0 & $\mathrm{X} 0$ & $\mathrm{X} 0.0$ & $=0.00$ & & \\
\hline$\square$ & 0 & $\mathrm{O}$ & 0 & $\mathrm{X} 0$ & $\mathrm{X} 0.0$ & $=0.00$ & & \\
\hline$\square$ & 0 & O & 0 & $\mathrm{X} 0$ & $\mathrm{X} \quad 0.0$ & $=0.00$ & & \\
\hline 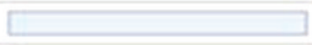 & O & 0 & 0 & $\mathrm{X} 0$ & $\mathrm{X} 0.0$ & $=0.00$ & & \\
\hline 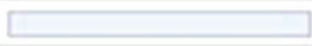 & 0 & $\mathrm{O}$ & 0 & $\mathrm{X} 0$ & $\mathrm{X} 0.0$ & $=0.00$ & & \\
\hline \multicolumn{3}{|c|}{ Highest AC load in Watts } & \multicolumn{3}{|c|}{ Total AC connected wattage at one time } & \multicolumn{3}{|c|}{ Total Watt-hours/day } \\
\hline & & & & & & & .00 & \\
\hline \multicolumn{3}{|l|}{ Total Watt-hours/day } & & \multicolumn{2}{|c|}{ Load correction factor* } & \multicolumn{3}{|c|}{ Corrected Watt-hours/day } \\
\hline 0.00 & & & & 0.70 & 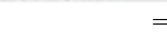 & 0 & & \\
\hline
\end{tabular}

FIGURE 4: Load evaluation form.

TABLE 4: Hourly distribution of the medium demand load 1.

\begin{tabular}{lccccc}
\hline Month & \multicolumn{5}{c}{ Hour of the day } \\
\hline \multirow{3}{*}{ May } & $0-4$ & $4-5$ & $5-6$ & $11-12$ & $18-23$ \\
October & $7-10$ & $6-7$ & $17-18$ & & \\
& $13-16$ & $10-11$ & & & \\
& $23-24$ & $12-13$ & & & \\
\hline \multicolumn{5}{c}{$16-17$} \\
\hline
\end{tabular}

Total daily $=25.476 \mathrm{kWh}$, total monthly $=764.28 \mathrm{kWh}$.

After taking into account the combined efficiency of the inverter and the battery:

Total daily $=29.297 \mathrm{kWh}$, total monthly $=878.922 \mathrm{kWh}$.

temperature which requires the use of a heating system while the house residents are sleeping and during their night life at the house causing an increase in the demand load. In other words, the load estimation during these months involves the use of the basic appliances such as refrigerators, lighting, computers, and television as well as a heating system.

Figure 7 demonstrates the actual required medium demand load throughout the day in January, February, and December.

Table 6 shows the estimated demand load in June, July, August, and September. This load is considered as the highest load throughout the year as these months have a high temperature which requires the use of air conditioning devices during the night life of the house residents as well as some fans throughout the day causing an increase in the demand load. In other words, the load estimation during these months involves the use of the basic appliances such as refrigerator, lighting, computers, and television as well as fans, and air conditioning devices. 


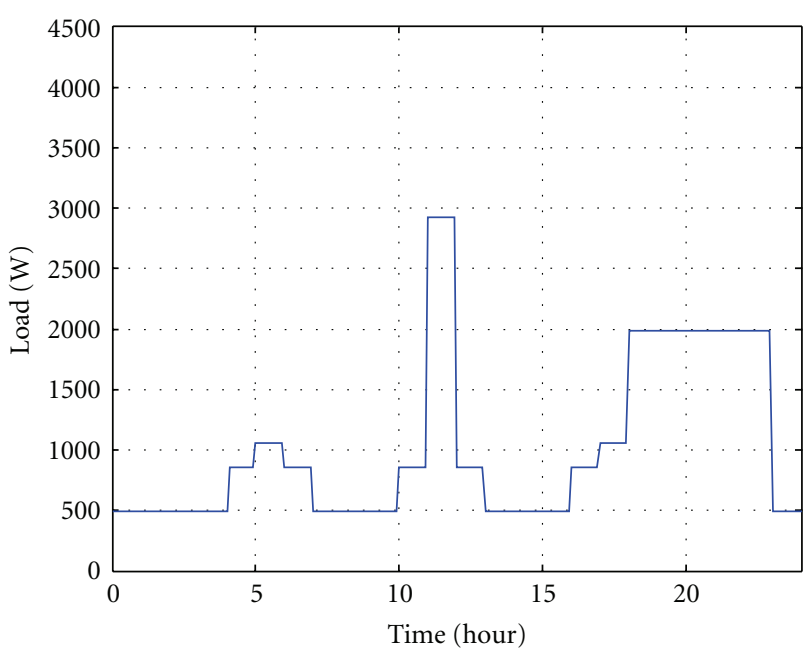

Figure 5: Variation of the low demand load throughout the day.

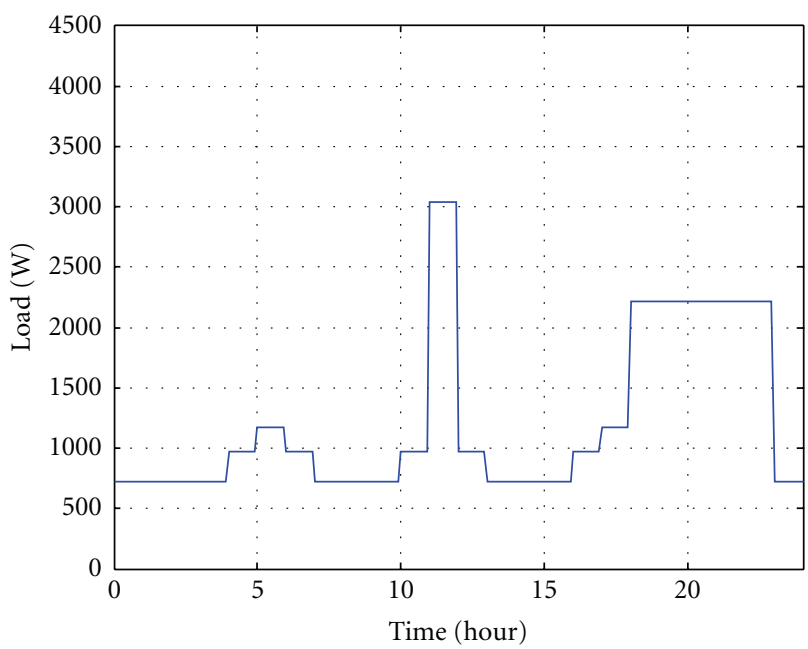

Figure 6: Variation of the medium demand load 1 throughout the day.

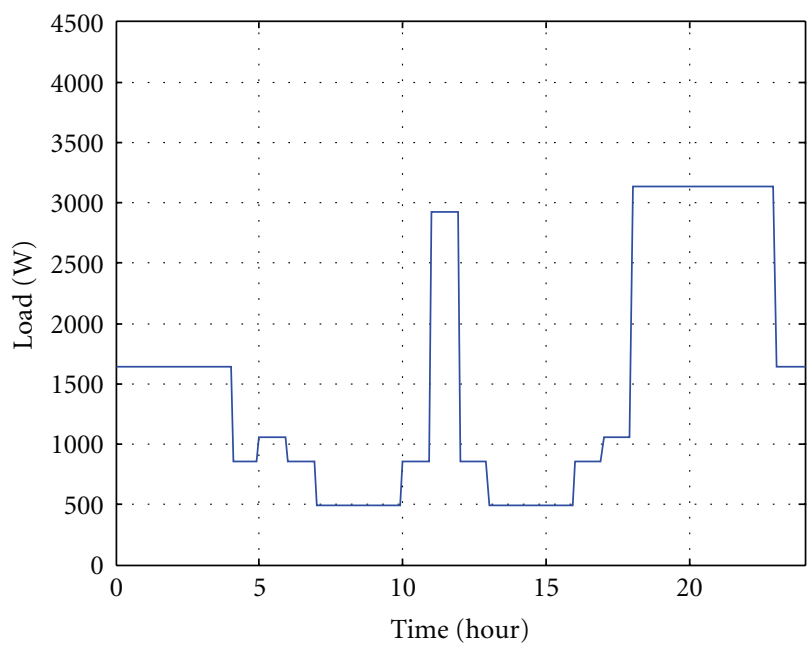

Figure 7: Variation of the medium demand load 2 throughout the day.
TABLE 5: Hourly distribution of the medium demand load 2.

\begin{tabular}{|c|c|c|c|c|c|c|}
\hline \multirow[t]{2}{*}{ Month } & \multicolumn{6}{|c|}{ Hour of the day } \\
\hline & $7-10$ & $4-5$ & $5-6$ & $11-12$ & $18-23$ & $0-4$ \\
\hline January & $13-16$ & $6-7$ & $17-18$ & & & $23-24$ \\
\hline February & & $10-11$ & & & & \\
\hline December & & $12-13$ & & & & \\
\hline & & $16-17$ & & & & \\
\hline Load $(W)$ & 432 & 742 & 923 & 2543 & 2725 & 1432 \\
\hline
\end{tabular}

Total daily $=31.976 \mathrm{kWh}$, total monthly $=959.28 \mathrm{kWh}$.

After taking into account the combined efficiency of the inverter and the battery:

Total daily $=36.772 \mathrm{kWh}$, total monthly $=1103.17 \mathrm{kWh}$.

TABLE 6: Hourly distribution of the high demand load.

\begin{tabular}{lccccc}
\hline Month & \multicolumn{5}{c}{ Hour of the day } \\
\hline June & $0-4$ & $4-5$ & $5-6$ & $11-12$ & $18-23$ \\
July & $7-10$ & $6-7$ & $17-18$ & & \\
August & $13-16$ & $10-11$ & & & \\
September & $23-24$ & $12-13$ & & & \\
& \multicolumn{5}{c}{$16-17$} \\
\hline Load $(W)$ & 632 & 842 & 1023 & 2643 & 3725 \\
\hline
\end{tabular}

Total daily $=34.476 \mathrm{kWh}$, total monthly $=1034.28 \mathrm{kWh}$.

After taking into account the combined efficiency of the inverter and the battery:

Total daily $=39.647 \mathrm{kWh}$, total monthly $=1189.422 \mathrm{kWh}$.

Figure 8 demonstrates the actual required high demand load throughout the day in June, July, August, and September.

Table 7 shows the actual consumption of electricity of an apartment with an approximate area of $140 \mathrm{~m}^{2}$ in which 4 adults live. This table is used as a sample of an actual demand load. This table shows monthly values of electric consumption which is much lower than the estimated values. This could be because the persons living in this apartment did not use all of the electrical devices available or they did not use the devices for all the time which is expected in the simulation. In other word, the consumption shown in Table 7 is just for one apartment and one family which could but does not necessarily represent the average electricity consumption for a $140 \mathrm{~m}^{2}$ apartment. Besides, the simulation tried to account for higher electricity consumption by the residents to allow for the satisfaction of more needs of the residents to use more devices. Thus, it is clear that the estimated demand is sufficient.

Another type of energy required by the house residents is hot water for personal use. Figure 9 shows the average daily hot water consumption for houses at different months throughout the year [22].

It was found that the maximum daily demand load after taking into consideration the $85 \%$ combined efficiency of the inverter and the battery (i.e., the power required from the PV) is $39.647 \mathrm{kWh}$ in July, August, and September, as shown in Figure 8. Besides, an average daily $10 \mathrm{kWh}$ of heating is 
TABLe 7: Actual electricity consumption of a $140 \mathrm{~m}^{2}$ apartment.

\begin{tabular}{|c|c|c|c|c|c|c|c|c|c|c|c|c|}
\hline Month & Jan. & Feb. & Mar. & Apr. & May & Jun. & Jul. & Aug. & Sep. & Oct. & Nov. & Dec. \\
\hline Load (kWh) & 377 & 352 & 346 & 316 & 343 & 337 & 466 & 920 & 904 & 769 & 507 & 403 \\
\hline
\end{tabular}

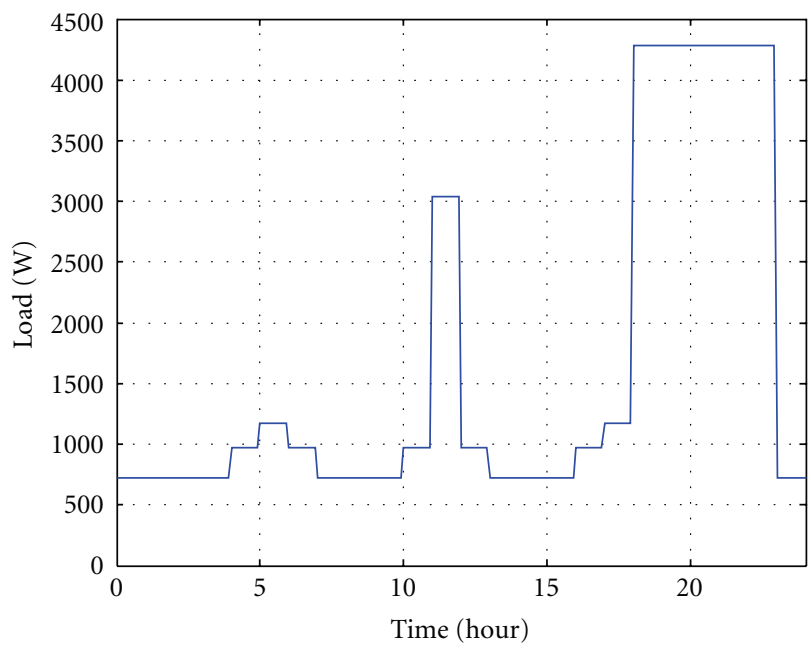

Figure 8: Variation of the high demand load throughout the day.

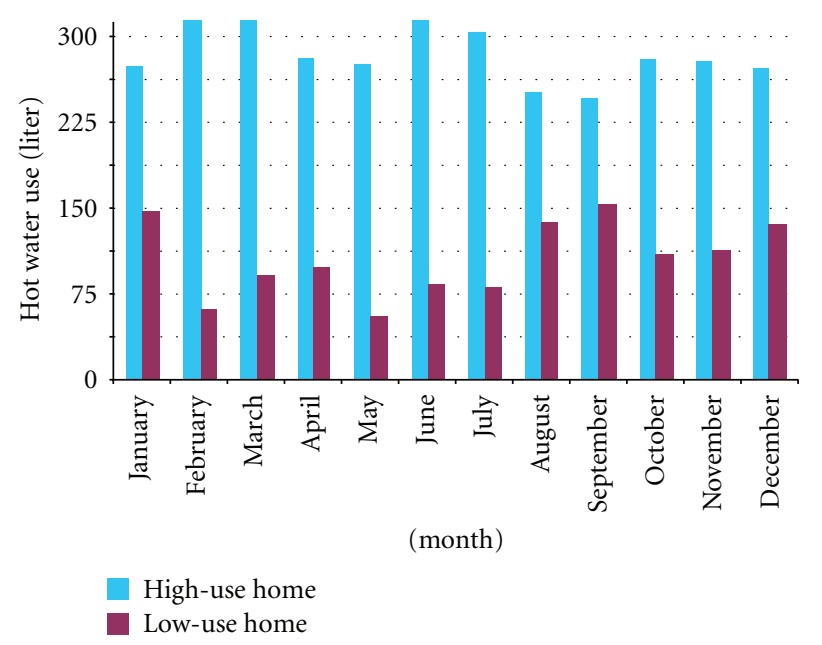

FIGURE 9: Average daily hot water consumption.

required to get the desired amount of hot water for personal use by the house residents shown in Figure 9 .

\section{Results}

It is required that for every month, the average daily output of the system satisfies the average demand load. Based on this requirement, the system will be optimized based on the economic analysis so that the COE is minimized. Thus, for every month, the required number of installed photovoltaic arrays is calculated and the COE will be calculated based on the month with the maximum number of required arrays.

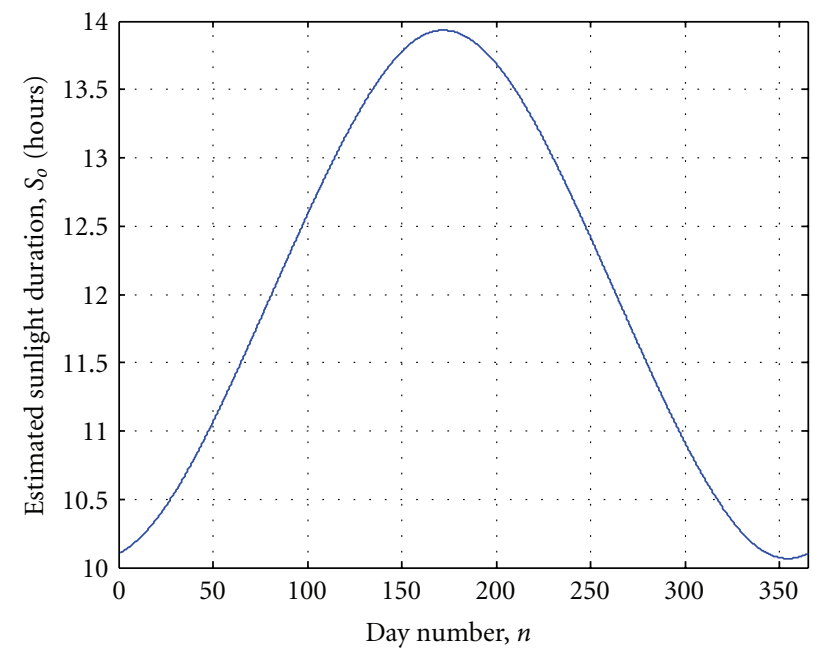

FIgURE 10: Theoretical daily sunlight duration.

6.1. Sizing of the System. The following curves represent the output data of the designed MATLAB code and were repeated while varying the different system parameters so as to obtain the number of PV arrays for every month.

Figure 10 shows the variation of the estimated sunlight duration throughout the year. It is clear that the difference between the maximum and minimum values of this duration in Cairo is around 4 hours.

Table 8 shows the values of the extraterrestrial irradiation as well as the daily irradiation for the average day of every month of the year. It is worth noting that the values of the clearness index shown in the table are assumed to be constant throughout every month.

Figure 11 shows the variation of the extraterrestrial irradiation as well as the daily irradiation for the average day of every month of the year. It is obvious that the value of the daily irradiation is less than that of the extraterrestrial irradiation by a factor (the clearness index) which has different values each month.

Figure 12 shows the variation of the total hourly radiation on the surface of the PV arrays (which are tilted by $30^{\circ}$ towards the south) throughout the sunlight duration for the different months of the year.

Figure 13 shows the optimum voltage which the PV cells will provide in order to obtain the maximum possible power from the PV arrays at any moment throughout the sunlight duration.

Also, Figures 14 and 15 show the power to be obtained from, as well as the efficiency of every $200 \mathrm{~W}$ solar panel throughout the sunlight duration and for different months.

As mentioned previously, the maximum daily demand load (i.e., the power required from the PV) is $39.65 \mathrm{kWh}$ in July, August, and September. Besides, $10 \mathrm{kWh}$ of heating 
TABLE 8: Calculated extraterrestrial irradiation and daily irradiation for the average day of each month.

\begin{tabular}{|c|c|c|c|c|c|c|c|c|c|c|c|c|}
\hline Month & Jan. & Feb. & Mar. & Apr. & May & Jun. & Jul. & Aug. & Sep. & Oct. & Nov. & Dec. \\
\hline Average Day & 17 & 16 & 16 & 15 & 15 & 11 & 17 & 16 & 15 & 15 & 14 & 10 \\
\hline$n$ (add 1 if leap year) & 17 & 47 & 75 & 105 & 135 & 162 & 198 & 228 & 258 & 288 & 318 & 344 \\
\hline$H_{o}\left(\mathrm{MJ} / \mathrm{m}^{2}\right)$ & 21.27 & 25.97 & 31.58 & 36.81 & 40.01 & 41.13 & 40.46 & 37.93 & 33.39 & 27.55 & 22.33 & 19.9 \\
\hline$K_{T}$ & 0.6159 & 0.6286 & 0.6395 & 0.6607 & 0.6721 & 0.6835 & 0.6897 & 0.6705 & 0.6503 & 0.6428 & 0.6405 & 0.6281 \\
\hline$H\left(\mathrm{MJ} / \mathrm{m}^{2}\right)$ & 13.1 & 16.32 & 20.19 & 24.32 & 26.89 & 28.11 & 27.91 & 25.43 & 21.71 & 17.71 & 14.3 & 12.5 \\
\hline
\end{tabular}

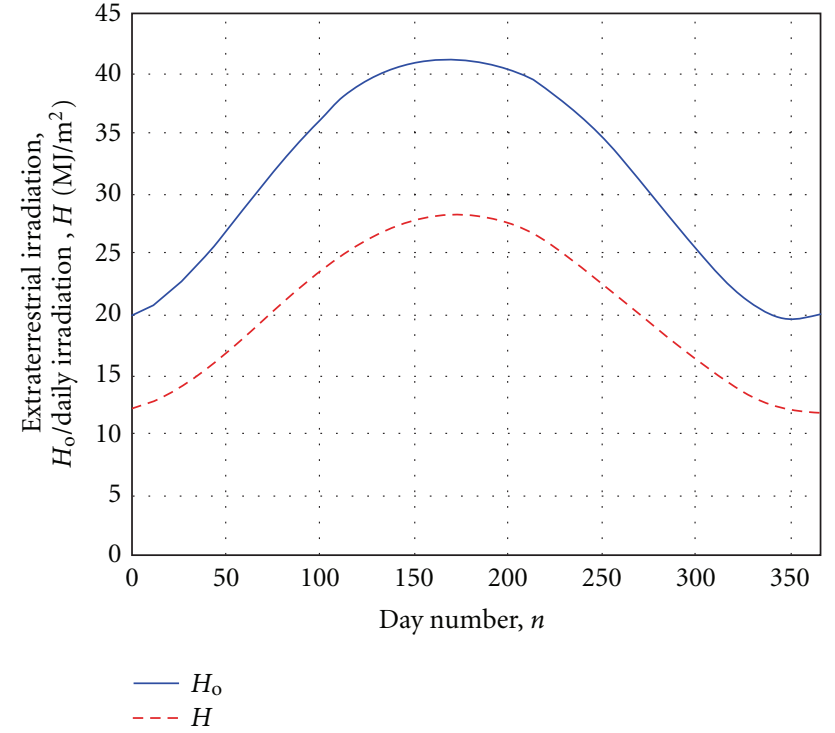

FIGURE 11: Daily values of $H_{o}$ and $H$.

to get the desired amount of hot water is required. Using the previous procedure, it was found that the average power obtained from the modeled $200 \mathrm{~W}$ PV array in September is $1.011 \mathrm{kWh}$ /day. Thus, $9.9 \mathrm{~kW}$ installed PV arrays would be enough to satisfy the average daily demand load in September. However, the lowest average power obtained from the modeled $200 \mathrm{~W}$ PV array is equal to $771.8 \mathrm{Wh} /$ day in December which has a daily demand load of $36.8 \mathrm{kWh}$ in addition to the $10 \mathrm{kWh}$ of heating. Thus, $12.2 \mathrm{~kW}$ installed PV arrays (i.e., 61 modules) would be enough to satisfy the average daily demand load throughout the year. However, the sizing of the battery and the inverter are based on the maximum demand load which exists in July, August, and September. Thus, the power of the batteries required is $41 \mathrm{kWh}$ and the maximum power to be handled by the inverter is $4.5 \mathrm{~kW}$ as shown previously in Figure 8.

\subsection{Optimization of the System}

6.2.1. Dual-Axis PV Solar Tracking. The optimum tilt angle of the PV arrays is equal to the latitude of the location $\left(30^{\circ}\right.$ in case of Cairo). However, one possible way to increase the radiation incident on the PV arrays is by using a solar tracker. That is, a setup that allows the arrays to be facing the sun throughout the sunlight duration.
Figure 16 shows the effect of using a solar tracker on the amount of hourly radiation incident on the PV arrays in January, April, July, and October. Although this effect is not recognized in January, it is clear from April, July, and October that solar tracking causes an increase in the amount of solar radiation incident on the PV arrays. This increase causes an increase in the output of the PV arrays (e.g., 31.4\% in April). However, in order to determine the economic feasibility of the solar tracking, we need to determine the reduction in the number of the PV modules as well as the cost of the solar tracker.

Using the MATLAB code, it is found that the number of $200 \mathrm{~W}$ PV modules in case of no solar tracking and $30^{\circ}$ tilt angle is 61 while in the case of solar tracking it is 59. This simply means a decrease by only 2 modules $(0.4 \mathrm{~kW})$ which saves $\$ 1056$ (i.e., $0.4 * 2640$ ). On the other hand, the cost of the solar trackers is $2.4 \$ / \mathrm{W}$ which causes an increase in purchase cost by $\$ 28320$ (i.e., $2.4 * 59 * 200$ ). Thus, it is not economically feasible to use solar trackers for the proposed system.

6.2.2. Cooling of PV Array Surface. Figure 17 shows the effect of the PV surface temperature on its $I-V$ curve. The increase in the surface temperature of the PV array has a negative effect on its efficiency as well as output power. Thus, it is proposed to use a cooling system comprising water as the coolant in order to keep the surface temperature of the PV arrays on average at $25^{\circ} \mathrm{C}$ and so increase the output power and efficiency of the PV arrays and at the same time slightly heat the water which can be used by house residents.

Figure 18 shows the effect of using this PV cooling system on the output power and efficiency of the PV arrays in January and July. It is clear that by using the cooling system there is a reasonable increase in the output of the PV arrays.

Using the MATLAB code, it is found that this increase in the power will cause a decrease in the number of required PV modules from 61 to 53 (i.e., 8 modules less which is equivalent to $1.6 \mathrm{~kW})$ ). This means a decrease in the purchase cost by $\$ 4224$ (i.e., $1.6 * 2640$ ). Therefore, cooling system of the PV is economically feasible. Table 9 shows a summary of the output used in the previous optimization part.

6.3. Performance of the System in Cairo. The following data about KC200GT were obtained from the code

(1) Shunt resistance: $R_{p}=601.336801 \Omega$.

(2) Series resistance: $R_{\mathrm{S}}=0.23 \Omega$.

(3) Efficiency of PV at nominal conditions: $\eta=14.184 \%$. 

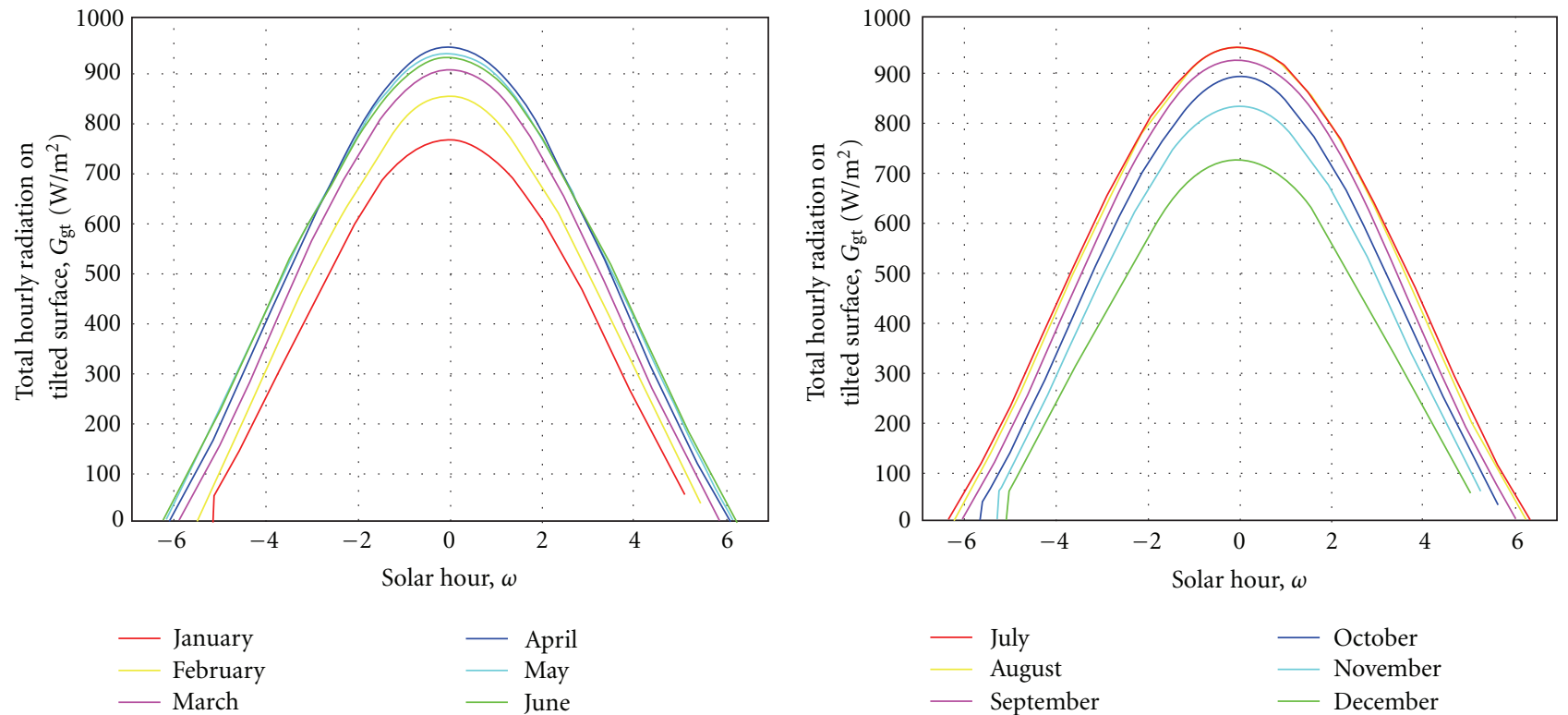

FIgURE 12: Variation of total hourly radiation on tilted surface $30^{\circ}$ in Cairo.
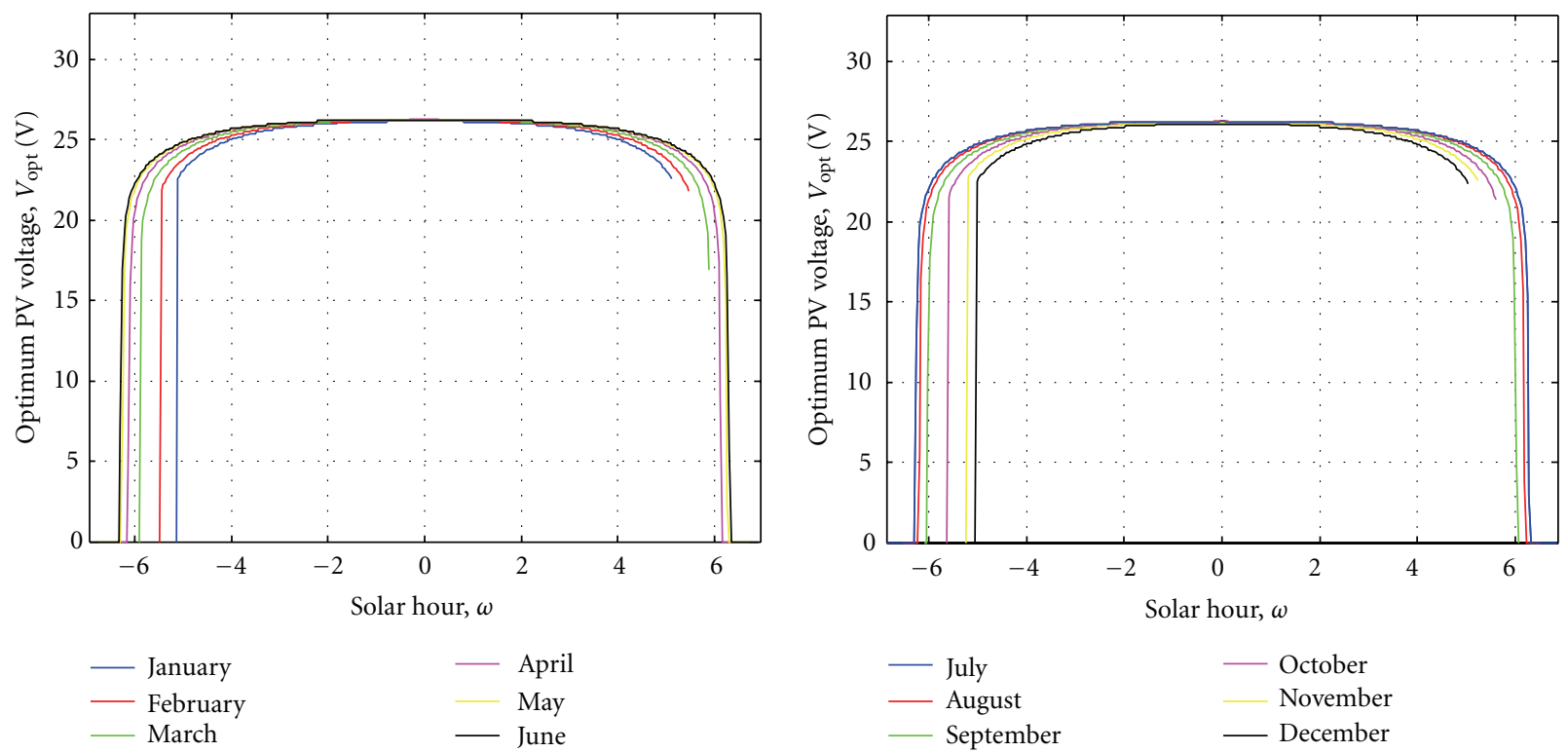

FIGURE 13: Variation of optimum voltage among sunlight duration.

(4) Average maximum efficiency in Cairo: $\eta=14.158 \%$.

(5) Average maximum power obtained in Cairo: $P_{\max }=$ 175.493 W.

(6) Maximum power obtained in Cairo: $P_{\max }=$ $188.926 \mathrm{~W}$.

Table 10 shows the purchase cost of each of the used components of the photovoltaic arrays and batteries system.

The COE of the proposed system is found to be $0.4174 \$ / \mathrm{kWh}$. To determine the competitiveness of the proposed system with the electricity produced in Egypt from conventional power plants, the recent cost of electricity is determined by using the data from the Egyptian electric utility and consumer protection regulatory agency [21]. The COE for a grid connected house is found to be $0.0557 \$ / \mathrm{kWh}$. However, an extra cost of $0.016 \$ / \mathrm{kWh}$ exists in case of considering removing $\mathrm{CO}_{2}$ produced by the conventional sources resulting in a total COE of $0.0717 \$ / \mathrm{kWh}$. Also, the proposed system has to be compared with other offgrid possible alternative such as using a diesel generator (conventional system).

Diesel Generator. It was found that the maximum possible hourly demand load is $4.28 \mathrm{kWh}$. Thus, $4.5 \mathrm{~kW}$ installed diesel generator would be enough to satisfy the maximum estimated demand load which occurs in July, August, and 

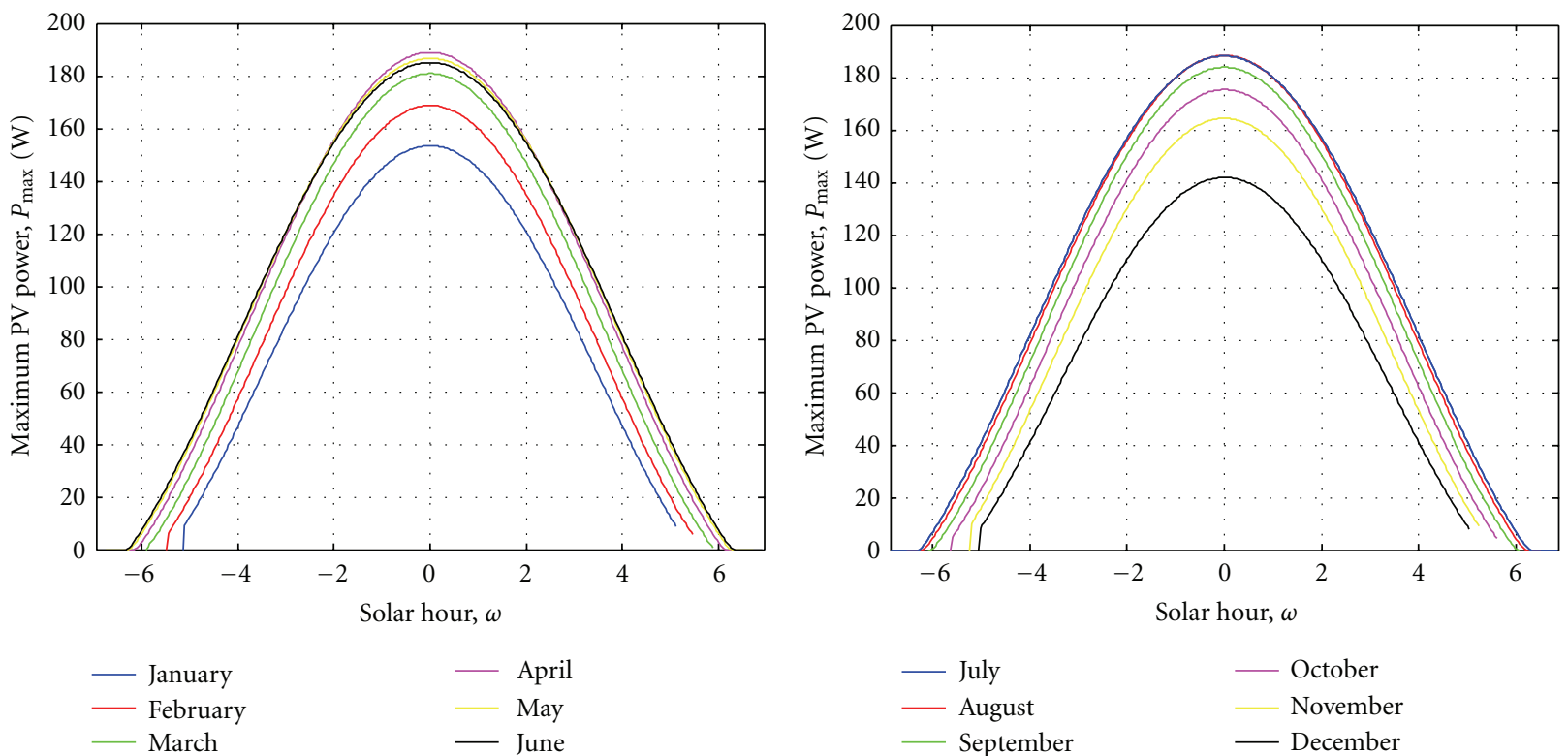

FIGURE 14: Variation of maximum power among sunlight duration.
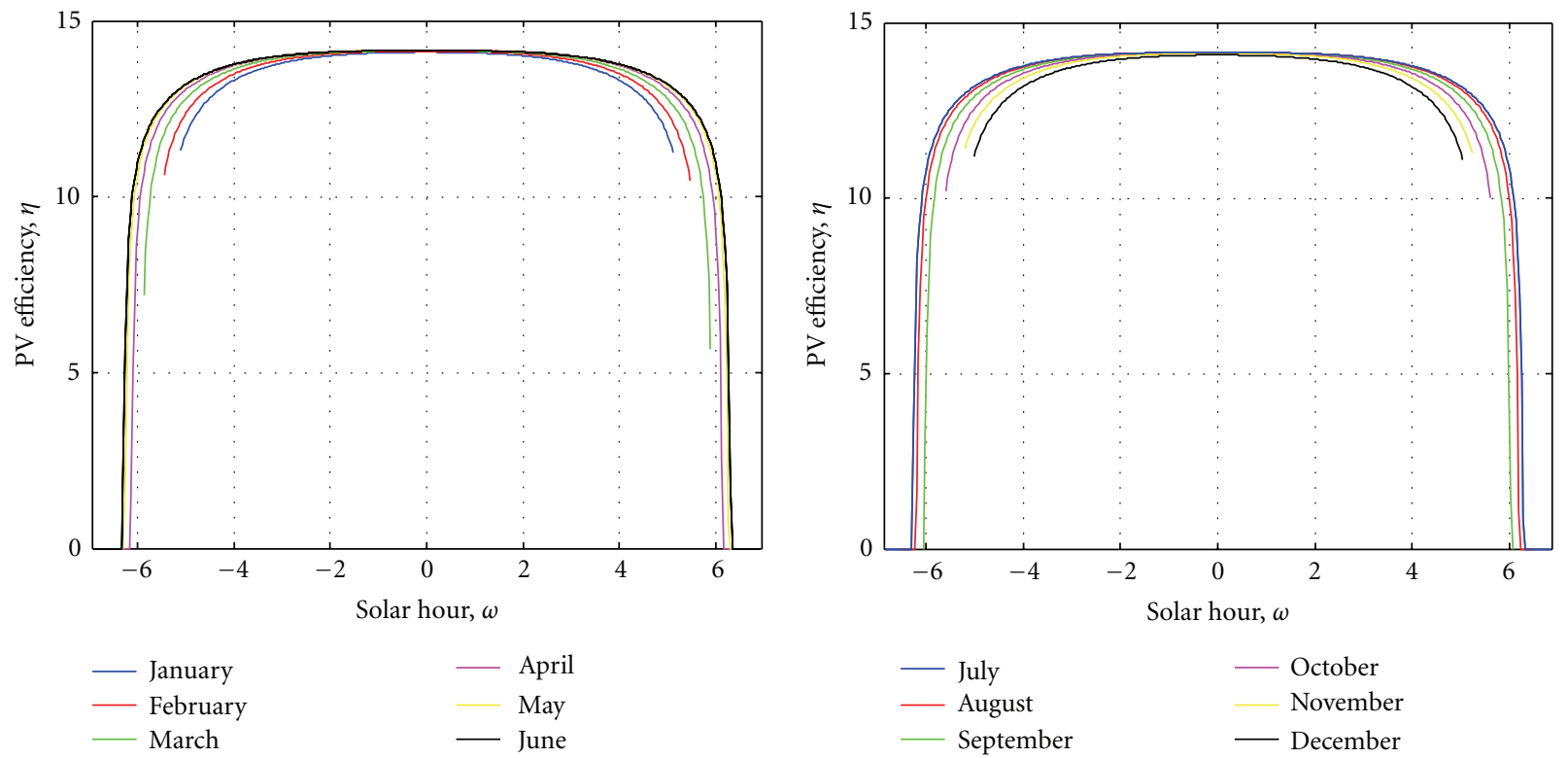

FIGURE 15: Variation of photovoltaic efficiency among sunlight duration.

September. Table 11 shows the purchase cost of each of the used components of the diesel generator system.

The COE by using this method is $0.2928 \$ / \mathrm{kWh}$. Also, an extra cost of $0.016 \$ / \mathrm{kWh}$ exists in case of considering removing $\mathrm{CO}_{2}$ produced by the engine resulting in a total $\mathrm{COE}$ of $0.3088 \$ / \mathrm{kWh}$.

It is clear from the previous results and as shown in Table 12 that using the system comprising photovoltaic arrays and batteries has higher COE than using the diesel generator. This is expected to be changed in the near future with the expected increase of the efficiency of the PV.
Effect of Increase of PV Efficiency. Figure 19 shows the effect of the increase of the PV efficiency from 10\% to 30\% (as is currently considered in the state-of-the-art research activities $[23,24])$ on the rated power of the PV arrays that power tends to decrease with a decreasing rate.

As a result of this decrease in the required installed power, the COE decreases by a decreasing rate as the PV efficiency increases. This is shown in Figure 20.

It is clear from Figures 19 and 20 that an increase of the PV efficiency results in an expected future COE of the system is $0.31 \$ / \mathrm{kWh}$. This is expected to be cheaper than using 
TABLE 9: Output data of demand load and required number of PV modules.

\begin{tabular}{|c|c|c|c|c|c|c|c|c|c|c|c|c|}
\hline Month & Jan. & Feb. & Mar. & Apr. & May & Jun. & Jul. & Aug. & Sep. & Oct. & Nov. & Dec. \\
\hline $\begin{array}{l}\text { Total daily electrical demand including } \\
\text { hot water demand }(\mathrm{kWh})\end{array}$ & 46.77 & 46.77 & 34.7 & 34.7 & 39.3 & 49.65 & 49.65 & 49.65 & 49.65 & 39.3 & 34.7 & 46.77 \\
\hline $\begin{array}{l}\text { Daily output power of } 200 \mathrm{~W} \text { PV } \\
\text { module (Wh) }\end{array}$ & 858.6 & 956 & 1038 & 1086 & 1058 & 1042 & 1044 & 1040 & 1011 & 943.8 & 878 & 771.8 \\
\hline Required capacity of PV $(\mathrm{kW})$ & 10.9 & 9.8 & 6.7 & 6.4 & 7.5 & 9.6 & 9.6 & 9.6 & 9.9 & 8.4 & 8 & 12.2 \\
\hline $\begin{array}{l}\text { Daily output power of } 200 \mathrm{~W} \text { PV } \\
\text { module with dual tracking (Wh) }\end{array}$ & 869.5 & 1047 & 1252 & 1427 & 1503 & 1530 & 1496 & 1406 & 1256 & 1047 & 868 & 796.3 \\
\hline Required capacity of PV (kW) & 10.8 & 9 & 5.6 & 4.9 & 5.3 & 6.5 & 6.7 & 7.1 & 8 & 7.6 & 8 & 11.8 \\
\hline $\begin{array}{l}\text { Daily output power of } 200 \mathrm{~W} \text { PV } \\
\text { module with cooling (Wh) }\end{array}$ & 968.7 & 1105 & 1229 & 1330 & 1347 & 1350 & 1362 & 1341 & 1269 & 1166 & 1053 & 879.4 \\
\hline Required capacity of PV (kW) & 9.7 & 8.5 & 5.7 & 5.3 & 5.9 & 7.4 & 7.3 & 7.5 & 7.9 & 6.8 & 6.6 & 10.7 \\
\hline
\end{tabular}

TABLE 10: System components' purchase cost.

\begin{tabular}{lccccc}
\hline Component & Price (US\$/Unit) & Replacement time (year) & Unit & No. of units required & Purchase Cost (\$) \\
\hline PV & 2640 & 20 & $1 \mathrm{~kW}$ & 10.6 & 27984 \\
Battery & 250 & 5 & $1 \mathrm{kWh}$ & 41 & 10250 \\
Charge controller & 133 & 20 & $1 \mathrm{~kW}$ & 4.5 & 600 \\
Inverter & 500 & 20 & $1 \mathrm{~kW}$ & 4.5 & 2250 \\
\hline
\end{tabular}

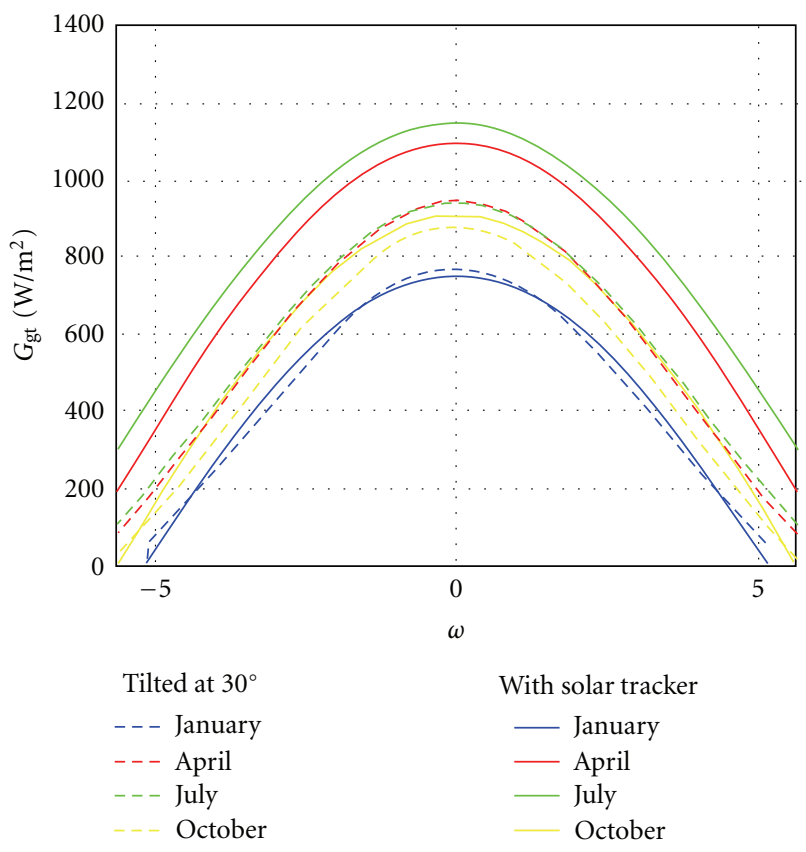

FIGURE 16: Effect of using a solar tracker on the amount of hourly radiation incident on the PV arrays.

a diesel generator when taking in consideration the expected increase of price of diesel in the future. In other words, a PV efficiency of $30 \%$ is will enable the solar system to be able to replace the diesel generator system. On the other hand, this COE is still 4 times higher than the current COE for a grid connected house.

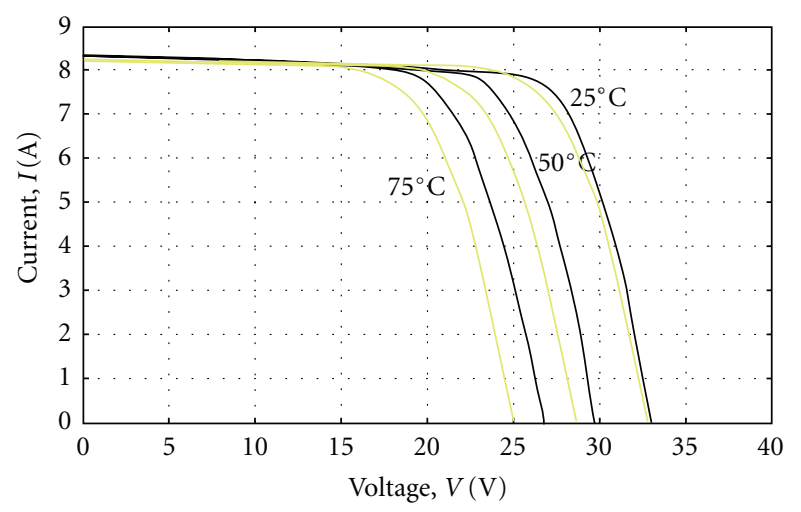

FIGURE 17: Calculated (yellow) versus experimental (black) curves.

\section{Conclusions}

Modeling of a solar powered stand-alone power system consisting of a PV and batteries was introduced by using simple equations. The variations of the output of this system were determined for Cairo city at different periods throughout the year. It was clear that the PV power varies in the same manner as the radiation on the PV surface which reaches its peak at the solar noon. Also, the efficiency of the PV is almost constant throughout the year as a result of using a cooling system to keep the surface temperature of the PV constant. Moreover, the proposed system can easily satisfy the estimated maximum demand load of the 4 family members.

In addition, the suitable sizing method for this system was explained in details as well as the economic study 

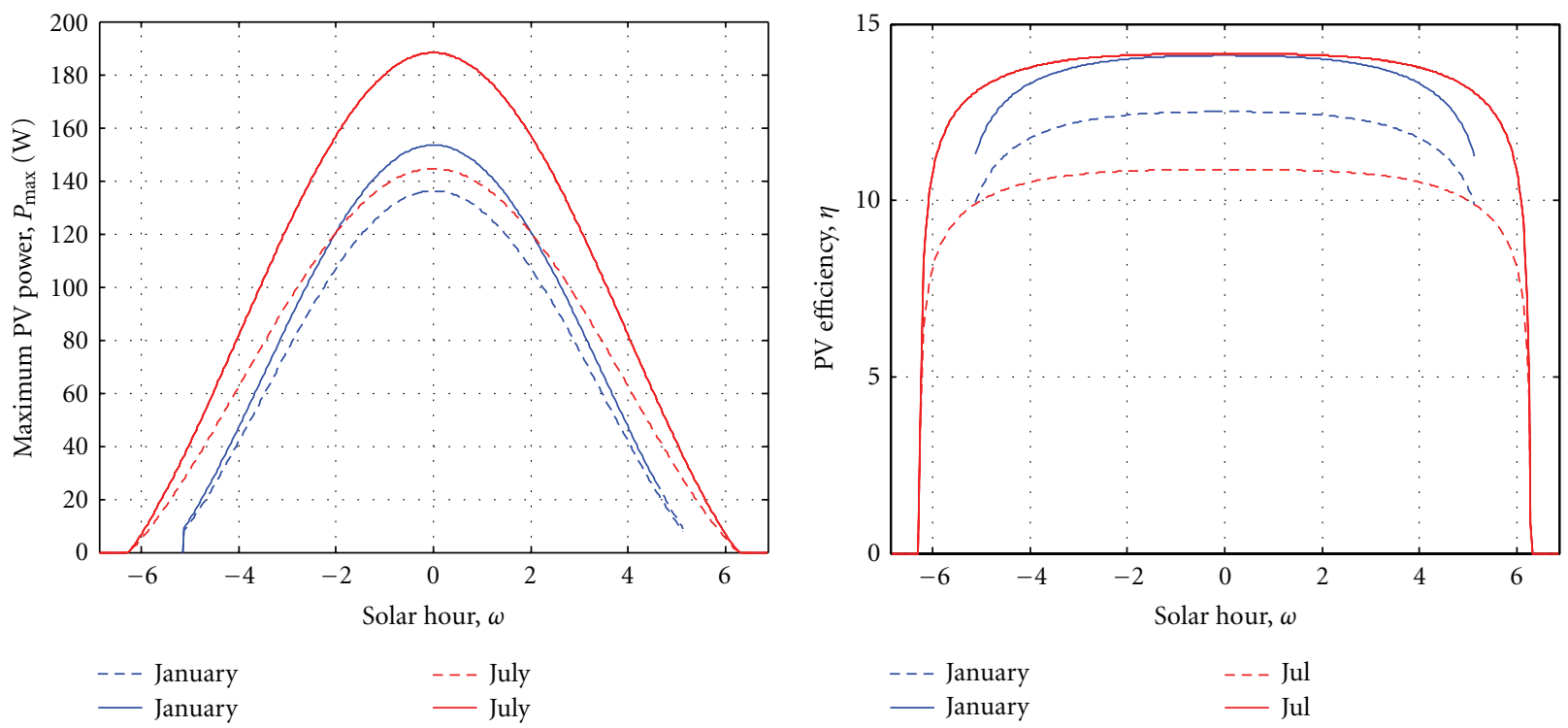

FIgURE 18: Effect of using PV cooling system (solid lines) on the output power and efficiency of the PV arrays.

TABLE 11: Purchase cost of diesel generator system components.

\begin{tabular}{lccccc}
\hline Component & Price (US\$/Unit) & Replacement time (year) & Unit & No. of units required & Purchase Cost $(\$)$ \\
\hline Generator & 500 & 20 & $1 \mathrm{~kW}$ & 4.5 & 2250 \\
Tank & 5 & 20 & 1 Gallon & 12 & 60 \\
\hline
\end{tabular}

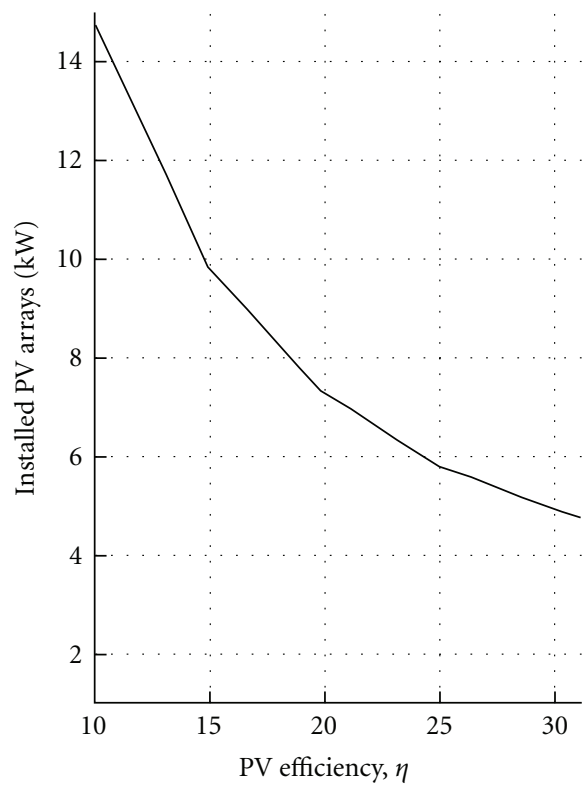

FIGURE 19: Effect of PV efficiency on installed power.

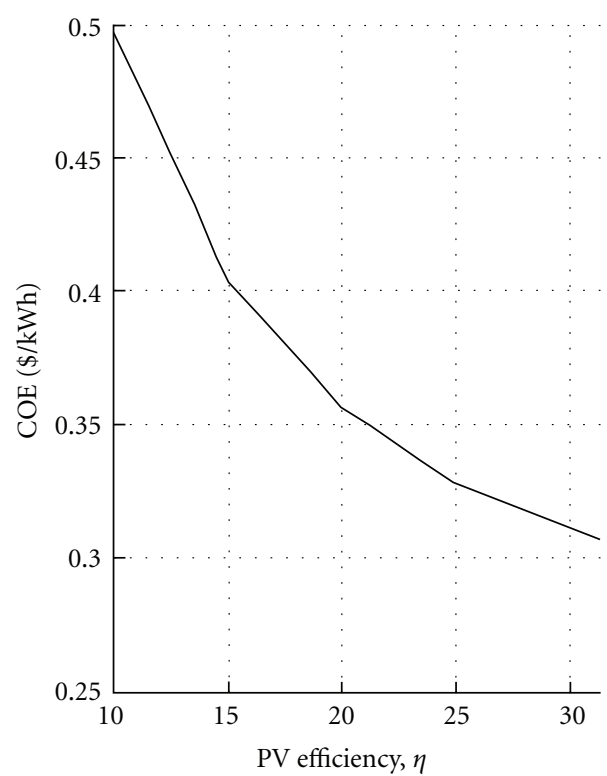

Figure 20: Effect of PV efficiency on COE. applied to determine the COE. Finally, the proposed system has a $\mathrm{COE}$ which is high relative to both off-grid diesel generator method of electricity generation and similar gridconnected house. However, this system is expected to be an economically feasible system in the future.

\section{Acknowledgments}

The authors of this paper do not have a direct financial relation with the commercial identities mentioned in this paper (e.g., "MATLAB, and RETScreen") that might lead to a conflict of interests for any of the authors. 
TABLE 12: Comparison of the cost of electricity generated from the 3 different systems.

\begin{tabular}{lc}
\hline System & COE (cents/kWh; US\$/Unit) \\
\hline Grid & 7.2 \\
Diesel generator & 30.9 \\
PV and battery & 41.7 \\
\hline
\end{tabular}

\section{References}

[1] J. A. Duffie and W. A. Beckman, Solar Engineering of Thermal Processes, John Wiley \& Sons, 3rd edition, 2006.

[2] A. Angstrom, "Solar and terrestrial radiation," The Quarterly Journal of the Royal Meteorological Society, vol. 50, pp. 121125,1924

[3] S. A. Khalil and A. M. Fathy, "An empirical method for estimating global solar radiation over Egypt," Acta Polytechnica, vol. 48 , no. 5, 2008.

[4] M. Collares-Pereira and A. Rabl, "The average distribution of solar radiation-correlations between diffuse and hemispherical and between daily and hourly insolation values," Solar Energy, vol. 22, no. 2, pp. 155-164, 1979.

[5] B. Y. H. Liu and R. C. Jordan, "The interrelationship and characteristic distribution of direct, diffuse and total solar radiation," Solar Energy, vol. 4, no. 3, pp. 1-19, 1960.

[6] B. Y. H. Liu and R. C. Jordan, "The long-term average performance of flat-plate solar-energy collectors. With design data for the U.S., its outlying possessions and Canada," Solar Energy, vol. 7, no. 2, pp. 53-74, 1963.

[7] M. G. Villalva, J. R. Gazoli, and E. R. Filho, "Comprehensive approach to modeling and simulation of photovoltaic arrays," IEEE Transactions on Power Electronics, vol. 24, no. 5, pp. 1198 1208, 2009.

[8] Kyocera, "KC200GT manual".

[9] C. Carrero, J. Amador, and S. Arnaltes, "A single procedure for helping PV designers to select silicon PV modules and evaluate the loss resistances," Renewable Energy, vol. 32, no. 15, pp. 2579-2589, 2007.

[10] D. L. King, J. A. Kratochvil, and W. E. Boyson, “Temperature coefficients for PV modules and arrays: Measurement methods, difficulties, and results," in Proceedings of the IEEE 26th Photovoltaic Specialists Conference, pp. 1183-1186, Anaheim, Calif, USA, October 1997.

[11] RETScreen ${ }^{\circledR}$ International, Clean Energy Project Analysis: RETSCREEN ${ }^{\circledR}$ Engineering and Cases Textbook, Photovoltaic Project Analysis Chapter, 2004.

[12] BBC, "Weather Centre-World Weather-Average Conditions-Cairo," 2010.

[13] W. De Soto, S. A. Klein, and W. A. Beckman, "Improvement and validation of a model for photovoltaic array performance," Solar Energy, vol. 80, no. 1, pp. 78-88, 2006.

[14] H. L. Tsai, C. S. Tu, and Y. J. Su, "Development of generalized photovoltaic model using MATLAB/SIMULINK," in Proceedings of the World Congress on Engineering and Computer Science, 2008

[15] R. A. Cullen, "What is Maximum Power Point Tracking (MPPT) and how does it work," Blue Sky Energy, 2000.

[16] http://www.bankrate.com/.

[17] http://www.tradingeconomics.com/Economics/Inflation-CPI .aspx?Symbol=USD.

[18] Y. A. M. A. Abdel-Raouf, Parametric investigation and econom$i c$ analysis of stand-alone and hybrid proton exchange membrane
(PEM) fuel cell system, M.S. thesis, Cairo University, Giza, Egypt, 2009.

[19] J. J. Hwang, L. K. Lai, W. Wu, and W. R. Chang, "Dynamic modeling of a photovoltaic hydrogen fuel cell hybrid system," International Journal of Hydrogen Energy, vol. 34, no. 23, pp. 9531-9542, 2009.

[20] http://www.absak.com/library/power-consumption-table.

[21] J. Wiehagen and J. L. Sikora, "Performance comparison of residential hot water systems," Tech. Rep. NREL/SR-55032922, National Renewable Energy Laboratory, March 2003.

[22] http://www.egyptera.com/ar/a-default.htm.

[23] E. Wesoff, "Alta Devices: Next Gen PV Challenges Status Quo," Solar Research and Analysis, Greentech Media, May 2010, http://www.greentechmedia.com/.

[24] U.S. Department of Energy, "Multi-Year Program Plan, 20082012," Energy Efficiency and Renewable Energy, Solar Energy Technologies Program, April 2008. 

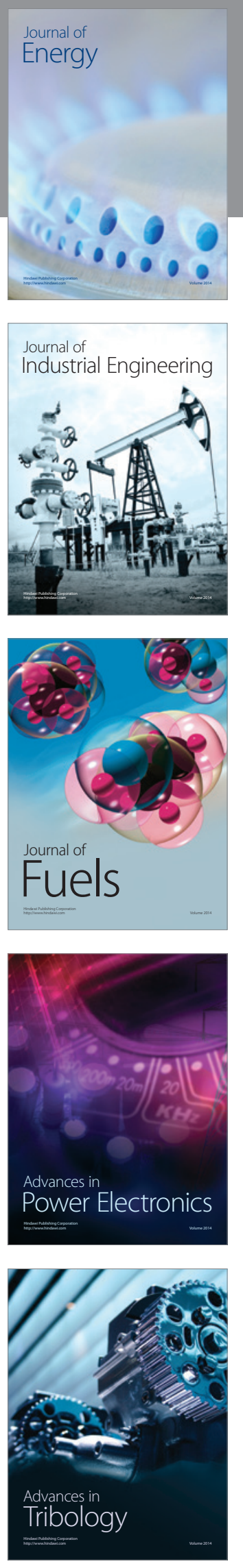
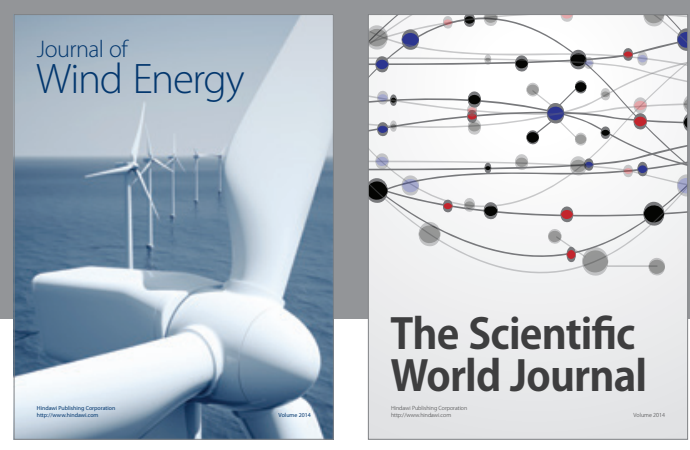

The Scientific World Journal

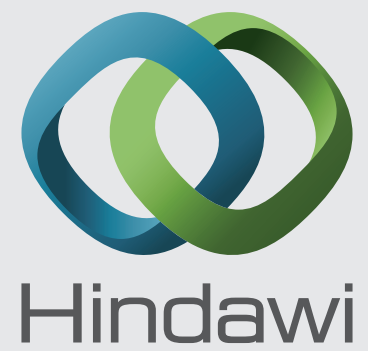

Submit your manuscripts at http://www.hindawi.com
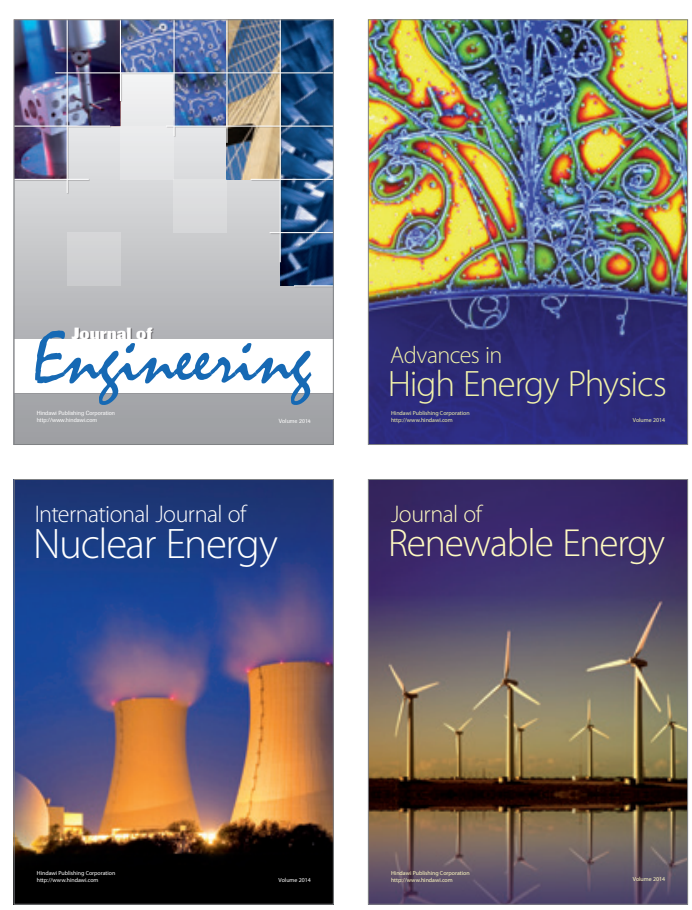

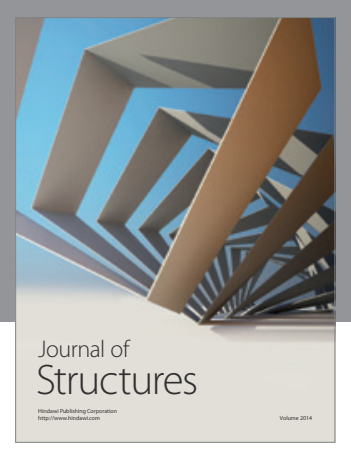

Rotating
Mechinery
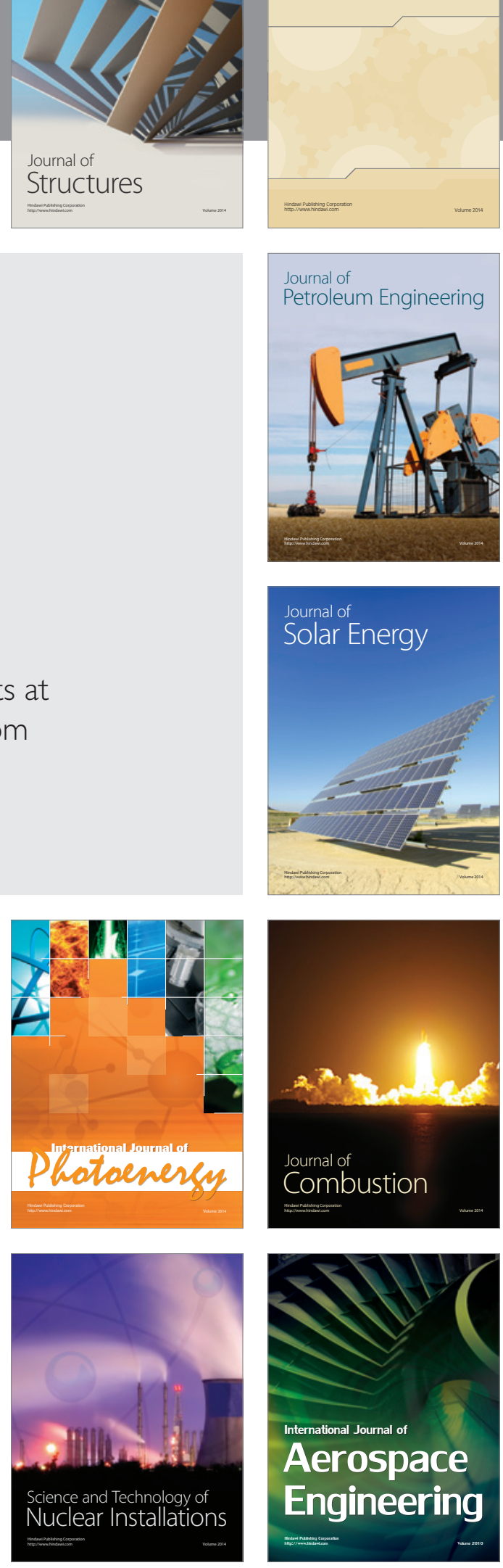